\title{
The Memory of Performance: From Contents to Contexts of Selected Tharu Folk Dances
}

\author{
Mohan Dangaura \\ Department of English, Trinity College, Kathmandu, Nepal \\ Corresponding Author: Mohan Dangaura, Email: mdangaura6@gmail.com
}

\begin{abstract}
The major objective of this paper is to analyze the historical context of the Dangaura Tharu folk dances of Nepal. The study discusses the Tharu subjectivity by assessing the performance as an agency. The primary discussion is based on the issue of Kamaiyahood in the songs narrated during the dance of the community. Dangaura Tharu ethnicity resides across five Tarai districts of Nepal: Dang, Banke, Bardiya, Kailali and Kanchanpur. This study is to identify and evaluate the role of memory in the folk performance of the community. It concludes by justifying the abundance of Kamaiyahood, spatial memory and empathy for nature in the community's folk performance. To collect the data required for the study, this study has adopted the qualitative research method, using the techniques such as direct observation, interview and relevant documents to understand the performing arts and rituals of the Tharus of Nepal. In addition, to analyze the collected data, Richard Schechner's idea of performance as a fortitude for identity has been applied critically. In addition, Alan Dunde's concept of folklore as the identity has also been considered. Thus, the study finds the memory of displacement inherent in the Tharu folk dance. The spatial memory and the Kamaiyahood appear as the dominant motifs in Dangaura Tharu folk performance. Since the dance of the community comprises the songs, reflecting the symbols and their meanings of the dances, for each dance has been critically analyzed in the paper.
\end{abstract}

Keywords: Folk dance, performance, ritual, memory, Kamaiyahood, subjectivity

\section{Introduction}

The Tharus are one of the oldest ethnic groups, inhabiting the plains of Tarai. Unlike the mainstream Nepali literature, the Tharu literature in its literary form has rarely been printed. Though the Tharu community is rich in their cultural performance such as folk dance, songs and rituals, the in-depth literary research has not been conducted in an academic field. Many studies have interpreted the basic lifestyle and historical habitat of the community. For instance, Dances of Nepal, a

SCHOLARS: Journal of Arts \& Humanities
Article History:

Submitted 26 September 2021

Revised 28 December 2021

Accepted 17 January 2022

Copyright Information:

Copyright 2022 (c) The Author(s). The publisher may reuse published articles with prior permission of the concerned author(s). The work is licensed under a Creative Commons Attibution 4.0 International License (CC BY 4.0).

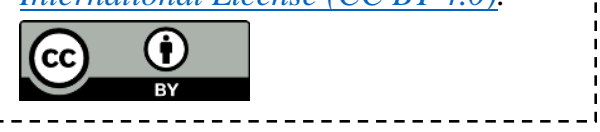

Volume 4, No. 1, February 2022 [pp. 11-28] 
research journal, edited by Govind Acharya and contributed by twelve authors, makes a brief discussion on the ritual of Sakhiya and Painya dance. Ashok Tharu argues about the inherence of existential philosophy of Tharu rituals such as the dance songs. He acclaims that such rituals are the rich accumulation of knowledge that deals with the concept of the universe:

Tharu folk literature arches out too many theories of origin like the Devine Theory, Theory of Special Creation, Big Bang Theory etc. In short, the Tharu folk literature indicates a time frame encompassing a period when the Tharus themselves wrote their cosmology, to the time when made the war of the Mahabharata was fought, and so on. (5)

Taking the reference of the content of their dance, it could be argued that the religious philosophies and mythological references are in abundance in their dance. As the paper presents the critical reviews of this field, it is easier for the readers to develop a general understanding of the folk dances.

The Dangaura Tharus of Nepal inhabit the part of Western Nepal from Dang to Kanchanpur. Since the time immemorial, they have been performing different folk dances as part of their community. The folk performance of Dangaura Tharu is practiced throughout the year, which is divided into different agrestic routines. It is distinguished into different genres according to their field work. For instance, the Sajana dance songs are recited during the rainy season to acknowledge the rain God. The Sakhiya dance is performed as the prayer to all the pagan Gods to bring the good harvest. Similarly, Jhumra and Chhokra are performed after the harvest to rejoice the production of crops. Interestingly, the Dangaura Tharu performance includes the themes of their daily experience recollected in their memory. Such memories include their topographical connotation, collective memory of Kamaiya practice and local governance. Being a clan of immense wildernesses of the plain land, the Tharu subjectivity also relies upon an ecological location for their livelihood. Thus, their performance mirrors the empathy and eco-cognizance towards the waning environment. Overall, the Tharu folk dances like Sakhiya, Sajana, Dhamar and Jhumra proliferate their spatial memory. In addition, the formation of Tharu subjectivity can be redefined and represented as the holistic beings by the critical analysis of their folk performance. Thus, the critical apprehension of their performance provides the readers much accurate sense of their subjectivity and culture.

\section{Review of Literature}

Folklore and its carrier group are defined in many different ways by different scholars. Alan Dundes is among such scholars whose extensive research of folklore has become the Bible for the aspirants of folklore studies. In his book The Study of Folklore, he defines the folklore group as the people who share at least one common factor and is confident that it will have some traditions, which it calls its own (Bauman 32). Thus, the folklore group can be deduced as the community sharing at least one common attribute.

Folklore includes a diverse area to be studied. It reflects the memory of the performers to their attitudes regarding topography and civilization. One similar usefulness is their ability to hold environmental attitudes of the performers. In the similar line, Yoon and Bunske define, "folklore is a living tradition reflecting the natural insights and perceptions of people" (637). Thus, folklores are helpful to interpret the history of the performers by assessing their desires, thoughts and mentalities.

Folklores have a wide category to be studied. One of the most useful and popular genres of the folklore has been the folk dance songs, which were continuously performed by the respective community. Folk songs embody the philosophy of the performers that were expressed in an indigenous way. Bunkse, in defining folk songs, finds them as the 
embodiment of the performers' collective soul, their muse, philosophy and history (561). Most of folk songs embody the very naïve experience of the rural society. Folklores also help us to explain the dwellings of the respective community. The community living in the mud house helps the people to understand the ecology of the surroundings. In the discussion of the house architecture philosophy, Ake Campbell assesses that the rural house designs follow the suitability of their environment (554). Houses in such communities do not stand alone against the environment surrounding it. The natural landscape of country-dwellers is located in the womb of nature that cannot be disintegrated and identified in separate entities.

The study of folklore also helps the readers to know about the source of creativity for the performers. To justify the argument, Mary Lewis contends, "The study of folklore and literature expands our knowledge on the creative process of their makers and possessors" (163). Thus, the research on folklore informs the readers about the artistic aptitude of the rural folks. Folklores express the collective heritage of the community. Thus, the ingenuity of the rural community should be justified no less scholarly than the academic scholars.

The folk performance functions as the site of commemoration, prayer and celebration. During the performance, the observers and participants remember their ancestry, pray their gods and celebrate the god's mercy. Richard Bauman also portrays folklore as the resilience against misfortune and bad fate (33). Sometimes, such gatherings are organized to demonstrate resilience and acceptance of specific discourses: from nature's catastrophe to its generosity.

On the other hand, William Bascom highlights the importance of folklore in a non-literate society. He explains the four functions of folklore: incorporating everyday life, justifying rituals and local institutions, and educating and censoring the misbehaviors. Folklores help to improve the moral and ethical behavior of the group. The function of reflecting, education and warning are expressed through the folklore performances. Hence, the folklore performance not only entertains the participants and observers, but it works as the therapeutic event by providing the outlets for the repressed wishes.

The folk dances combine diverse themes, ranging from romance, comedy to tragedy. All these genres emanate from the social behavior and practice. In a true sense, the social actors' actions are being imitated as the performance, categorizing them into different genres. Philip Barry differentiates the folk ballads into two types: "the ballad of the situation and the ballad of introspection ... the ballad of situation impresses the listeners and observers by the realism of action whereas the latter one by the centrality of the chief character ... they may represent misfortune and lamentation" (274). Thus, the songs comprise the consented action of folks in which they develop a collective agency.

R. L. Tongue explores the motif and symbols in the folk songs. He finds the folklorists often use very common and abundant objects around them as particular symbols such as the flowers for women, trees for protection and birds for good and bad signs (293). The references of local flora and fauna are the prominent styles to sew the lore and to provide the performers a sense of connectivity with the place.

The songs for the Tharu folk dance are the concoction of their peasantry life. The performance includes a ritual of worshipping to their pagan gods and a prayer to bless them with good harvesting. On her extensive field research about the folk performance of Tharu community, Victoria Marie Dalzel observes the whole cycle of agrestic life in the Tharu folklore $(89,91,104)$. Her study also found the narration of Kamaiyahood in the most Jhumra and Maina songs. Their performance recounts the unlawful Kamaiya 
practice. They even commemorate their displacement from the inner valley of Dang to the plains of western Nepal.

The discourse on the Tharu subjectivity has often misled the non-Tharu's perspective about the Tharus. In his field research among the Tharus of Chitwan, Arjun Guneratne found the Tharu identity quite misunderstood. His findings conclude that such incredible identity discourse about the Tharus is often popularized by the non-Tharu tourist guides. They have often presented them backward, primitive, and jungali people (535). Thus, such false narratives about the Tharus hinder the elegant side of their folk performance. The community holds much productive folklores even if the pace of modernity may not have touched the community in comparison to the rest of the world. The Tharus inhabit the lowlands of the Tarai region. Thus, their rituals are assimilated with nature, agriculture and subject of the past.

The Tharu folk songs can be divided into ballads, epics, tales, proverbs and riddles. They can be further classified as rituals, festivals, seasons and work songs. The general folk songs are performed anytime irrespective of rites and rituals, seasons, festivals, etc. Sajana and Mynah are the Tharu seasonal songs performed during the rainy season. The completed study on the Tharu community only discusses their anthropological evolution. Thus, the Tharu rituals and performance need to be studied more from the perspective of visual culture as well.

\section{Methodology}

This study conducted on the Tharu folk dances: Sajana, Sakhiya, Jhumra and Maghauta utilizes the qualitative research method on the narratives performed during the exhibitions of the rituals, using the techniques such as direct observation, interview and relevant documents. For the interpretive discussion of the dance narratives, the paper interprets the definitions and probable contexts of folklores since the folk dance is a subgenre of this arena. Next, the paper focuses on the distinct contents of the selected songs to study the symbols and motifs of the narratives. This study has used the ideas obtained from the interviews by the folk singers whose songs have been included in the paper.

Although their narration is not used explicitly, the interview helped this study a lot to use it for interpretation in the most acute way. The narration of the dance has been sketched from the songs of YouTube videos as their anthologized versions have not been published in any medium: neither digital nor print. The photographs included in the paper are shot by the mobile phone camera during the researcher's field visit. The photographs are shot in different times accordingly to capture different rituals. The area where photographs were shot are the Khonpur village, the Kanari village and the Bhada homestay located in and around the periphery of Dhangadhi Sub-Metropolitan City.

The study area of this paper hovers around the performance of the Tharu community residing in Dang, Banke, Bardiya, Kailali and Kanchanpur districts of Nepal. The study has used the theoretical insights developed by Alan Dundes on folklore studies and Richard Schechner on Performance Studies. The narration of the dance songs has been extracted from the songs. Thus, to prove the contextual critical apprehension of the performance, the narration of the songs has been interpreted explaining the motifs they behold.

The study appropriates Richard Schechner's concept of dance and ritual as the demonstration of social codes and conducts (29). The folk dance as a performance imitates the daily affairs of the performers. The community reflects on everyday ritual through such dances like Sakhiya, Jhumra and Mungrahuwa. In defining the imitative quality of performance, Schechner derives the ideas from Aristotle's idea of mimesis to define aesthetic as social experience. Thus, Schechner finds the ritualistic dance 
stimulated by the collective engagements and the spirit (40). Correspondingly, on defining, "the ritual as performance" (my quote), Victor Turner states, "Ritual may be a stereotyped sequence of activities involving gestures, words and objects, performed during a sequestered place and designed to influence preternatural entities or forces on behalf of the actors' goals and interests" (Deflem 5). Turner visualizes the performers' actions in the course of performance to decipher the motifs frequently used by them. Thus, this study interprets the Tharu folk performance from Schechner and Turner's concept of everyday ritual as the performance.

\section{Results and Discussion}

There are numerous instances in which the folklorists have conducted their research by accumulating the data received for their study. The folklores collected and published under different research programmes have rarely focused on the critical interpretation of their collections. The folklores collected under any themes should be critically analyzed to decipher their historical implications. Therefore, to globalize the folklore studies, this paper examines the context of Dangaura Tharu folk dance songs in the light of spatial memory and the Tharu subjectivity as Kamaiya. As Dundes's concept emphasizes the criticism of lore, this study attempts to analyze the performance critically. Dundes has primarily examined the contexts of the folklores to extrapolate the memory of the performers.

The Dangaura Tharu folklores rehearse the tradition, memory and sense of space. For instance, Dhamar, Jhumra, Mynah, Sajana and Mangar unfold different layers of the community's memory. The performers demonstrate their relationship with the landscape and their subjectivity. The songs include a sense of displaced ecoindividual, loss of native space, the symbolism of animals, birds and plants. Since the lore is performed throughout the year, each dance has its own specific context. Though most of them are agrestic in tone, not all performances simply blend the annual routine of the peasants. The dance songs often get replaced with new phrases and motifs. For instance, Dhamar could be about the family separation during the festival of Maghi. Similarly, Mangar could be the anxiety of a woman who leaving her home after the marriage. Thus, the analysis of the composition of their performance helps the readers to create more authentic interpretation.

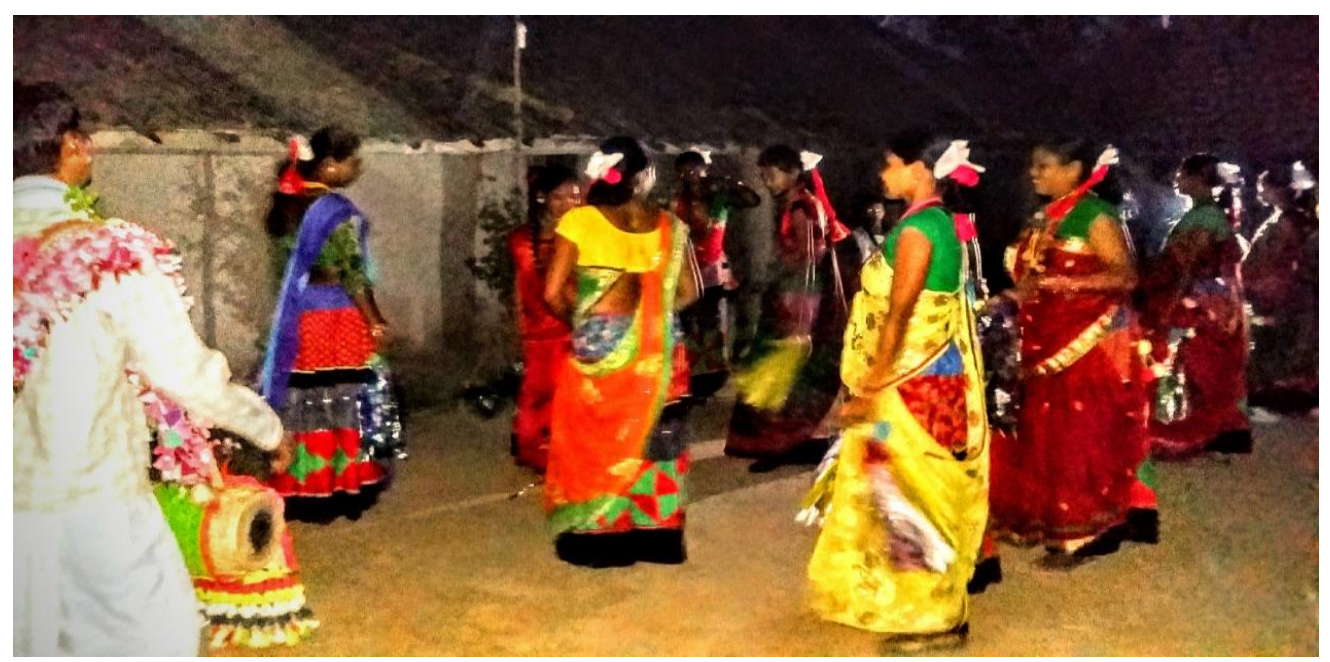

Fig. 1. The Tharu women performing Sakhiya at Bhada Homestay, Dhangadhi in 2017. Source: Snapshot from the researcher's field visit 
Since a wide range of definitions of folklore has often put the readers and researches in mess, Dundes attempts to change the cliché of folklore definition. In "Folklore as a Mirror of Culture," he defines folklore as an autobiographical ethnography (55). So, they are the performers' own version of their description. Their performance should not be perceived as the relic of their past, but as an expression of contemporary issues. He discovers such performance as an occasion to promote one's ethnocentrism. Nonetheless, such contexts would also assist the community through their artists as Franz Boas believes to discharge "social sanctions, suppressed wishes, and anxieties" (55). For instance, the community performs the Jhumra mourning over the Kamaiya practice.

Maghauta and Sakhiya are often performed to appease their ancestral gods (see Fig. 1). These rituals help them to be more autonomous through the public demonstrations. They help them to assert their agency in social strata.

Chhokra, Dhamar, Jhumra, Mangar and Sajana have their own respective contexts in the Tharu community. Among them, Chhokra and Jhumra embody the initiation of puberty and adulthood as well. Dhamar signifies the commencement of Maghi and Mangar is recited as a farewell song for a bride during the wedding. Similarly, Sajana resembles the initiation of paddy sowing. Dundes considers such folklores as the occasions to deal with the crucial stages of one's life. He asserts, "Folklore in all cultures tends to cluster around the critical points in the life cycle of the individual: birth, initiation, marriage, death and the calendrical cycle of the community: sowing, harvesting" (64). The folk performance of the Tharu community revolves around diverse subjects such as Jhumra reflects the cordial relationship between the sister-in-law and brother-in-law. Many of these performances include the fantasy of the creators and the artists as well.

By the same token, the Maghauta dance song (performed at Maghi) from the Buhran Tharu film describes the early bathing of a woman when she loses her tikuli (fingertip ornament). Besides, her sendur ("vermilion") also gets expunged by the water. The song performed at Maghi bears the tradition of rising early in the morning, taking baths and receiving blessings from the elders of the family. During the fiesta, the boys cooperatively dance with girls performing as mandrahuwa ("madal player"):

Babaki sagar gainu ha muriya lahane

Sakhiye ho kajula chhutal pani ghat

Sakhiye ho gataiya chhutal pani ghat ("Babaki Sagar" 0:30-3:00)

I went to the father's pond to take the head bath

Oh friends, my kajal got washed away by the water

Oh friends, I forgot my shawl at the water-dam (Trans. is mine)

In the course of Maghauta dance, a typical ritual is performed. During the latter part of the performance, the woman picks up the money scattered on the blanket. While she picks up the money with her mouth, she has to backflip her body. She has to bend her head supported by her hands and pick the money. This popular custom performed by women during Maghi is commonly known as Paisa Lutaina ("offering the money").

The theoretical postulation of the folklore is important to understand them critically. In ethnography, Dundes claims that just the collection of lore cannot help to critically assess the meanings of the performances. The literary interpretation should be meant for disseminating motifs with specific substance in any folk performance. Thus, he expresses his dissatisfaction with the social science scholars who simply store the field data. He believes that such acts do not differentiate one lore from the other. The gathering of data only will leave the readers blank about the semantics of the performance. He validates the difference as: 
The problem is that for many folklorists, identification has become an end in itself instead of a means to the end of interpretation. Identification is only the beginning, only the first step. Folklorists who limit their analysis to identification have stopped before asking any of the really important question about their material. (70)

The folklorists must be able to address the above queries. The soundness of academic subjects, thus, emerges from the critical interpretation of social behaviors. However, it was Bronislaw Malinowski who first discussed the fallacy of collecting mere texts. $\mathrm{He}$ disagreed with the folklorists' methodology: "The text, of course, is extremely important, but without the context, it remains lifeless" (qtd. in Dundes 80). A comprehensive analysis of oral literature is required. Thus, the efficacy of context to interpret the meaning of a text should always be prioritized.

Folklore provides insights on the community performance. It might sound like a light version of history, but there are basic differences between them. The former includes the social behaviors: events, beliefs, customs, ceremonies, materials and skills of a particular group, the latter holds on to the factual situations. In the essay "Is it Folklore or History?" Tom Crum answers how folklore can be the significant approach to comprehend history:

A people's perception of their history is often formed not so much from knowledge of facts as from the traditional knowledge passed on to them through folklore. A great many people are much more familiar with folklore's rendition of an historical event than they are with the actual facts of the event, and this form their opinion and sets the standard for "truth" as to the event. (5)

Folklore responds to the spectators and artists more proficiently than that of a historian's. The visual performance persuades the respective community much effectively about their memory than the academic facts. Thus, the visual performance suffices as the best approach to persuade them about their memory.

Folklore makes use of animate characters. The Tharu folk songs too incorporate the animate characters: birds, animals, trees, flowers and even the natural landscapes. Graham Anderson discusses the association of flora and fauna with the signs of good and bad fate across the folklores. He exemplifies the use of birds and trees, bringing a reference from the Greek and Roman folklore. He believes that such lore represents the nature as sacred to the respective community: "It might be a mountain top, a grove in a wood, or some similarly remote place, where the supernatural can be readily evoked or imagined or where previous associations can be drawn on" (Anderson 168). Thus, such diverse uses of animal mythology could also be witnessed in the Tharu folklore.

In the Barka Banwa folk song, the artists relate the natural topography to their religious beliefs. Banshakti Mata ("Goddess of forest") who protects the folks from the enchantments of the forest is often referred. The people of the Basanta corridor worship the bumps on one of the trees, believing it to be the elephant god. According to their faith, the elephants crossing through the Basanta biological corridor visit the tree and pay their homage. In addition, the reference of "Swans" is also visible in their songs. Thus, the animated usage of these creatures reinforces the notion of an animate world, signifying the existence of distinct life behavior among all the entities.

The folk song Barka Banwa ("Big Forest") describes the diverse geographical locations in the Basanta corridor. The Basanta corridor extends around Kailari Village Council, which consists of nine wards where the Ratanpur ward is primarily located around the corridor. The Ratanpur ward villages: Basanta, Ratanpur, Rampur and Bhuinyaphanta are located around Barka Banwa that sustain their economy through the ecological diversity of the corridor: 
The Memory of Performance: From Contents to Contexts 18

Barka Banwa Basanta me aai

Chali jaibi banuwa bihare

He banwa me phule lagal kesh

Semra me dhota phule re

Bari me basanti fuli gainai, banma Katkuiya fule re

Asharai me paki gaila jam, jhairi gaila fula ashrai

Jau dadu rukhuwa me kosham ture, pakli gulariya bhail masawa

Ghodaghodi Vishanu ullas, ashar me behadak mela

Banashakti mata he patiya charahaibu, para karaeu barka banuwa re ("Barka

Banwa" 0:30-3:00)

Oh friends, welcome to the Big Forest Basanta, will go to roam in it

The flowers of kesh and the semul tree have started to bloom

In the garden, the basanti flower has bloomed, the lily flower blooms in the

forest

In the month of June/July the jamun fruits get ripened and the flowers of silk

cotton tree fly lightly

Oh brother climb the tree and pluck the Kushum fruits

The god Vishnu rests in the Ghodaghodi temple, the Behada Baba temple fair occurs in July

I will offer the leaves to the goddess Banashakti (Forest Goddess), please help me cross the jungle safely (Trans. is mine)

The folk song celebrates the biological diversity: silk cotton tree ("kapok"), jamun ("Indian blueberry"), and sal tree ("shorea robusta") are being referred in the song. The song welcomes the visitors to the forest and offers them an expedition to the biological corridor. It describes a reproductive cycle of jamun tree; the month of June/July brings the flowers to semul tree and fruits to jamun.

The social rules and philosophical ideas behind the society's functions are inherent in the rituals of a community. Clifford Geertz finds that an interpretation of cultural performance is necessary to understand the meaning of a complex cultural web (qtd. in Yengoyan 270). He synchronizes the interpretation of the text with the interpretation of culture since the text is the production of a certain culture. Thus, for him, a specific description of culture is necessary to interpret the symbols in that cultural performance. The textual interpretation of Tharu folk songs signifies an annual life cycle of a Tharu whose life in the past and still at present remains around the peasantry. Carol Rosen in her review of Schechner's performance theory finds such performance as a study of the use of aesthetic perspective in social psychology (253). She interprets Schechner's notion of performance as an art whose subject, structure and action are social processes. She interprets Schechner's performative theory as an approach that studies everyday life as an art.

Since the humans possess the capacity to develop concepts and are physically more privileged to produce their concepts into practice, they have culture, art and innovations. Bruce McConachie critically examines Schechner's performative theory that designates Homo sapiens more sophisticated than the animals in art and aesthetics. He asserts, "Humans can make conventions for dancing, ritual, and other folk performances. They can step in and out of their roles as dancers, beauty queens, and musicians in order to rehearse and perform for others. Performance by humans is possible due to the presence of conceptual integration among them" (42). McConachie finds the performance aesthetic possible in the humans since they possess the capacity to form and conceptualize the ideas into an exhibition. Similarly, Deborah Kapchan reveals the performative arts and rituals as a medium of certain messages. She argues, "To perform 
is to carry something into effect - whether it be a story, an identity, an artistic artifact, a historical memory, or an ethnography" (479). In this ways, the Jhumra songs narrate their peasantry, longing for space and family relations. They transmit the participants from their hierarchy to the mass. These performative occasions, as Turner's idea of liminality, reflect the hierarchy of the community and at the same time end that hierarchy.

In a Jhumra folk song, Raj Kushmy refers to the Tharu aantwa ("watch tower constructed in the middle of the farm for reconnaissance; here in sense of observing the wild animals"). The song describes a folk plaiting rope while a male guards his farm sitting on the tower. Women knit the deluwa, dhakiya ("basket") comforting themselves on aantwa:

Boy-Ari he sure ura, sura ura ho bahere purbaiyaa

Are aatwa me baithike gori, panuwa dar dori binai

Girl-Delawa ke panuwa mor heri chhayaluwa muski maralo

Sakhiyai ho nachati hasati bajhal maiya mor

Boy-Ari he jhura ura jhura bahe jamuna ho

Are jaune ghata gori lahawai, sugina boli marnai ("Tharu Jhumra Song" 0:30-

Boy-The wind blows from the east

The lady weaves the rope sitting on the tower

Girl-The boy smiles looking at the pattern of my basket

Oh friends I fell in love dancing and laughing

Boy- Oh, dear the Jamuna River flows gaggling through the trench

The parrots sing on the ford where the beauty takes bath (Trans. is mine)

They feel cool and fresh when the east wind blows around aantwa in the summer. The expression of aantwa and the entanglement of youths in a joyous affair has always been one of the dominant themes in Chhokra and Jhumra. Thus, whenever Jhumra is performed, the Tharu youths cordially involve themselves in the celebration enriched by music and dress.

The folk dances are the behavior of the rural communities. They guide the community for specific rituals. E. Phillips Barker defines folk dancing as "Dancing which has evolved among the peasantry and is maintained by them in a fluid tradition without the aid of the professional dancer, teacher or artist" (qtd. in Buckland 317). Thus, Buckland, on tracing the definitions of folk dance, asserts the birth of such dance performances from the perspective of the peasantry life. Stetson Kennedy also observes the folk dance as natural and profoundly spontaneous (318). Buckland catches the improvised structures of folk dance in the rural communities. Nancy Lee Chalfa Ruytes defines the existent of folk dance on two bases. First, she finds the folk dance solely produced by and for the folk community themselves. Second, she finds the folk dance existing for diverse purposes. She asserts, "They can exist as the content of research, fun, sport, hobby and larges communication" (269). For her, the folk dance holds diverse means to entertain the participants and observers. Thus, the folk dance should be appreciated and studied with the genre, having the multiple qualities in them.

The folk performance embodies the history of a particular community since they have been practiced from times immemorial. Folklores blend myth, epic, history and cultural values of the communities. John Greenway interprets the folk songs as the sociohistorical approach. For him, understanding folk songs helps any scholar, researcher and observer to dwell deep into the socio-historical values of a particular community. He finds the ballads of folk songs perfectly representing the community feeling: "The form of literature which best suits the alley is the ballad. A striking proof of the influence 
which poetry combined with music possess aver the human mind, even when most hardened and depraved" (5). Rita J. Martin finds folklores quite useful for children to develop their language power. She argues, "As a result of singing, hearing and reading folk songs, expressive and receptive vocabularies increase" (326). Thus, the syntax of the songs also helps to develop language proficiency and research skills in children.

The Tharu folksongs reflect the community's memory of Buhran ("displaced migration from inner Dang valley"). According to the popular narrative, the migration occurred when the Tharus could not withhold the pressure of the hill caste community who tricked them. The Mynah and Sakhiya songs often reflect the nostalgia for their native space. The Tharus who did not wish to live a disturbed life preferred to migrate from their first habitat to the plains of Tarai. The songs not only reflect the soreness of getting displaced, but also they narrate their suffering under the Kamaiya practice. The privileged community oppressed them to work under the harsh circumstances in the fields paying minimum wages. However, they failed to resist it due to the lack of collective social agency and illiteracy. Thus, the intolerable suppression forced them to migrate from their native place. The song from the movie Buhran (2007) expresses the journey of similar displacement:

Are maina eka ranga jogiya,

Saure ranga basiya, oh, maina

Tilaranga, tilaranga, suno jogiya basiya bajaita, ho maina

Ari maina eka ranga jogiya, saure ranga basiya

Oh maina, jogiyake basiya bhauji suna ke suhawan

Dadu kahi, basiya bhauji, sunake mahirawan, oh maina ("Tharu Mynah Song" 0:30-3:00)

Hey mynah, all our body looks similar but the why the tunes of flute differ The hermit is playing the flute tiri riri, tiri riri

Hey mynah, all our body looks similar but the why the tunes of flute differ Hey mynah, listen how melodious tune the hermit is playing, oh sister-in-law

The brother's flute too sounds very pleasing (Trans. is mine)

The woman in the song expresses different shades of life relating to the different tunes played by the hermit. The jogi's ("hermit") tune in multiple rhythms exposes the longing for their native space. The memory of suppression is unveiled through their tunes.

During the interview, Basanta Chaudhary and others also express the similar diasporic longing in their Mynah song:

Kheti karnu maina, adhya bataiya re bardha buti jotbu

Magha mahina buti tirabu, uhe hal hui

Magha pugal kokni, Dashya pugal dhana

Jhandimandi tanaka jail jaibu buhran ho maina,

Danga mai chhornu, Deukhuri mai lagnu

Baba mai chhornu, Dai mai chhornu ("Tharu Mynah Song" 0:30-3:00)

Oh mynah, I worked in the farm as the sharecropper

Will pay the tax after the harvest and will still be in poverty

The kokni (broken rice) will last upto Maghi and the rice will last only upto

Dashain

Will pack up my belongings and leave for Buhran, Oh mynah

I have to leave my father; I have to leave my mother (Trans. is mine)

In the dramatic performance of this song, the artists express their grief on living with bare income under the sharecropping system (also see Fig. 2). They articulate their underprivileged life. The income from their minimum products cannot empower them as they have to repay the loan received from their landlords. The kamaiyas ("male bonded 
labourers") could not hope for better life since their life has stuck in the poverty. They become unable to wish for progress. Thus, they mourn on being exploited by their landlords. So, the song expresses the pain of leaving one's native place.

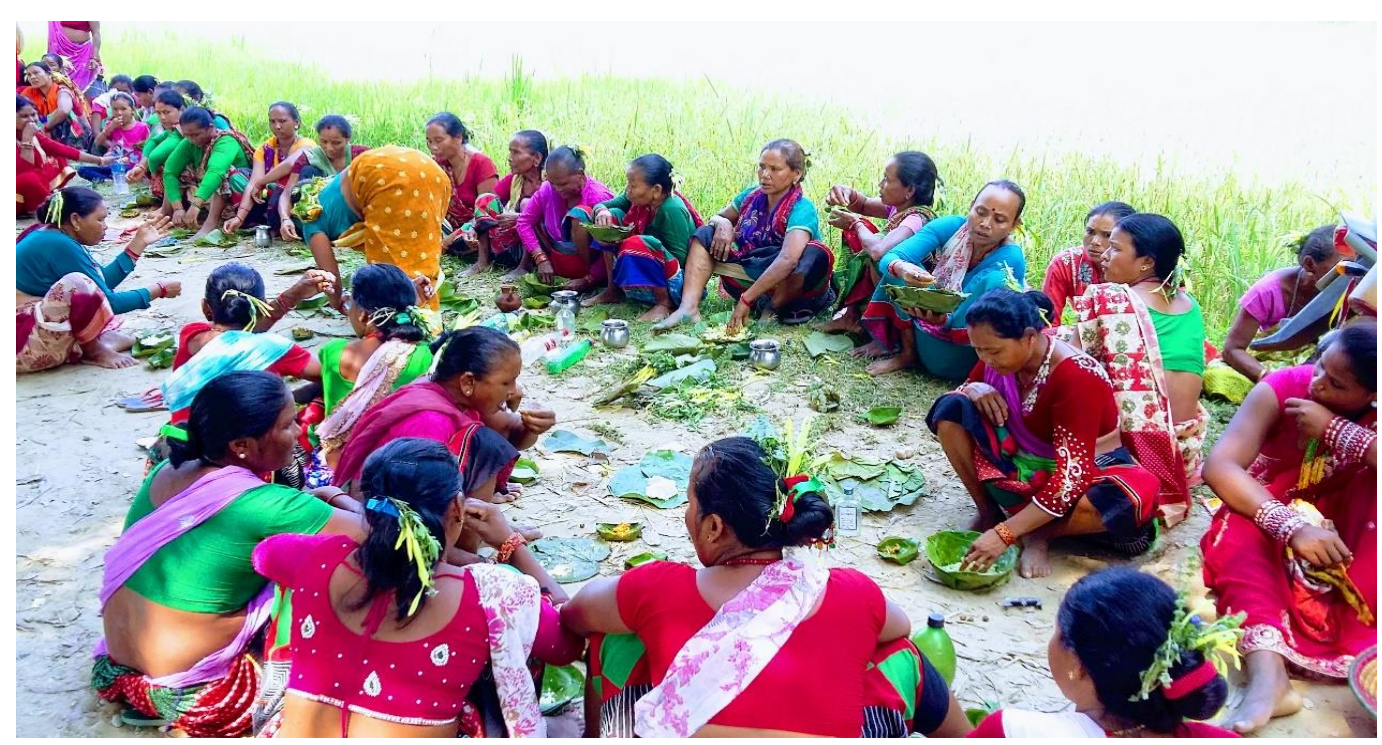

Fig. 2. Women gathered for Pittarauhuwa also popular as Pittar Asraina at riverside ("ritual of paying homage to dead ancestors") marking the initiation of Dashain. 2017. Source: Snapshot from the researcher's field visit

Jugree and Mani Chaudhary are the housewives whose songs have been uploaded on the YouTube by the aspirants of folklores whose Mynah song also expresses the hope for better life. The song involves a lady hoping to emigrate with her brother-inlaw to a prosper place. Her dream is channeled through her cordial relationship with her bhatu ("brother-in-law"). She reflects on their passionate chitchat:

Aaina jaina bhatu, maiya lagaina, ho maina

Batachita karna bhatu, ghara suta jaina ho Maina

Ye papi maiya ruaitha dinarat ho maina

Hari ho maina, pipra pahata turi kagada banaibu ho Maina

Hatha anguri kati kalam banaibu ho maina

Khara khara, khara khara chithiya likahibu ho maina

Purbi bayal chali, chithiya pathai ho, ho maina

Jibi jibi kalo ho bhatu, aash kil lagailo, ho maina

Budhaka din bhatu parbi thekan ho Maina

Pokari makura, ghunaiya lagi gila ho Maina

Thalika siddha bhatu, dukari katailo

ho Maina

Jibi jibi kalo bhatu

Vauka luga bhatu, motari badhailo, ho Main

Jaibi jaibi kalo bhatu ashra kil lagailo, ho Maina

Mokri ka luga bhatu, dukari katailo ho Maina

Kahiya ta pugaibo bhatu, hi mor desha bhatu ("Tharu Mynah Song" 0:30-3:00)

Oh brother-in-law! your frequent visit has begotten love in me

Oh brother-in-law, please go to your house after the chitchat

This evil love has made me weep day and night, oh mynah

Oh mynah, I will pluck the leaves of Peepal tree (Sacred fig) and make them the papers 
The Memory of Performance: From Contents to Contexts 22

I will write my spontaneous feeling on them

The east wind will carry my letter to you, oh mynah

You promised to elope, you just made me wait, oh mynah

The clothes of the bundle have been worn out, oh mynah

The mice have torn the packed luggage,

You just made me pack the large goods

You promised to elope but only made me wait, oh mynah

When will you take me to the good-far country, oh brother-in-law (Trans. is mine)

The woman expresses her innate desire to abscond from the Dang valley with her brother-in-law to a promised land. However, she communicates her disappointment with him as she is worn out of his promise. She expresses her annoy as her packed clothes and food grains have all gone old and torn. All her collections are swarmed by the parasites and her preparation has ruined. Moreover, her brother-in-law comes to be a trickster who makes his fake promises. Thus, she communicates her unfulfilled dream of acquiring an affluent life in a prosperous place.

Resham Chaudhary's song Har Jowata Uthal Kamaiya ("The labor woke up at dusk to plough") from the film Kamaiya explains the making of a kamaiya subjectivity. The lives of kamaiya and kamlahari ("female bonded labourer") do not improve even after their perusal throughout the year. The song echoes the agony of being a bonded labour. The kamaiya is obliged to live a miserable life. Thus, the song reveals us about the routine job of a kamaiya:

Har jowata uthal Kamaiya bihanake lug lug jarame

Dheki kuta uthal kamlari, andhariya rat bhuar bihan ma

Fongi fonga choliya goniya, fatal fatal chaubandi jhuluwa

Sukha dukkha hamar janam, korti bital gaunk kuluwa

Kapuwa bhat sinkike jhowara, chaurasi byanjan hamara

Har juwa, chhatri wo lathi sanghariya ho, gham ojrar

Lahriya, bhaisa, goru wor chhegri, barhdhan hakti orait janam

Chhabal jaanr hamar kamjori, astaha futal karam ("Har Jowata Uthal Kamaiya 0:30-3:00)

The kamaiya wakes up in the shivering cold of dusk

The kamlahari wakes up in the early morning to beat the wooden rice grinder

The tattered blouse and skirt

The worn out patched shirt

With ups and downs, the life passed digging the watercourse (man-made streams in villages),

The rice flour soup with sinki (gundruk, preserved fermented vegetable) are our delicious dishes (84 dishes)

Plough and yoke are our friends throughout the day and night

The life passed driving oxen cart, and shepherding bulls, goats, oxen

The wine is our weakness,

We have a spoilt karma (Trans. is mine)

The kamaiya wakes up promptly in the dawn to furrow the field of his landlord. The kamlahari also wakes up to grind the rice on dheki ("wooden rice pounder"). She suffers the physical and mental torture. She bears the social stigma for being a servant at another's home. In anticipation of cash and loan, the Tharu women were forced to work at their landlord's house. Thus, they had to be the victims of domestic abuse. Similarly, a kamaiya's dresses are always worn-out. His entire life has passes delving the streams in the village to facilitate the farm water. His nourishments are very basic: kapwa ("flour 
soup") and sinki ("preserved dry vegetable"). He keeps himself busy with a wooden plough and yoke, chhatri ("umbrella made of bamboo stripes and leaves utilized during paddy planting"). His life has been confined as a shepherd. In the last verse, the speaker blames his habit of drinking jaanr ("rice wine popularly produced in the Tharu community") for his destitution (see Fig. 3). Because of the propensity for heavy intoxication, he could never improve the standard of his life.

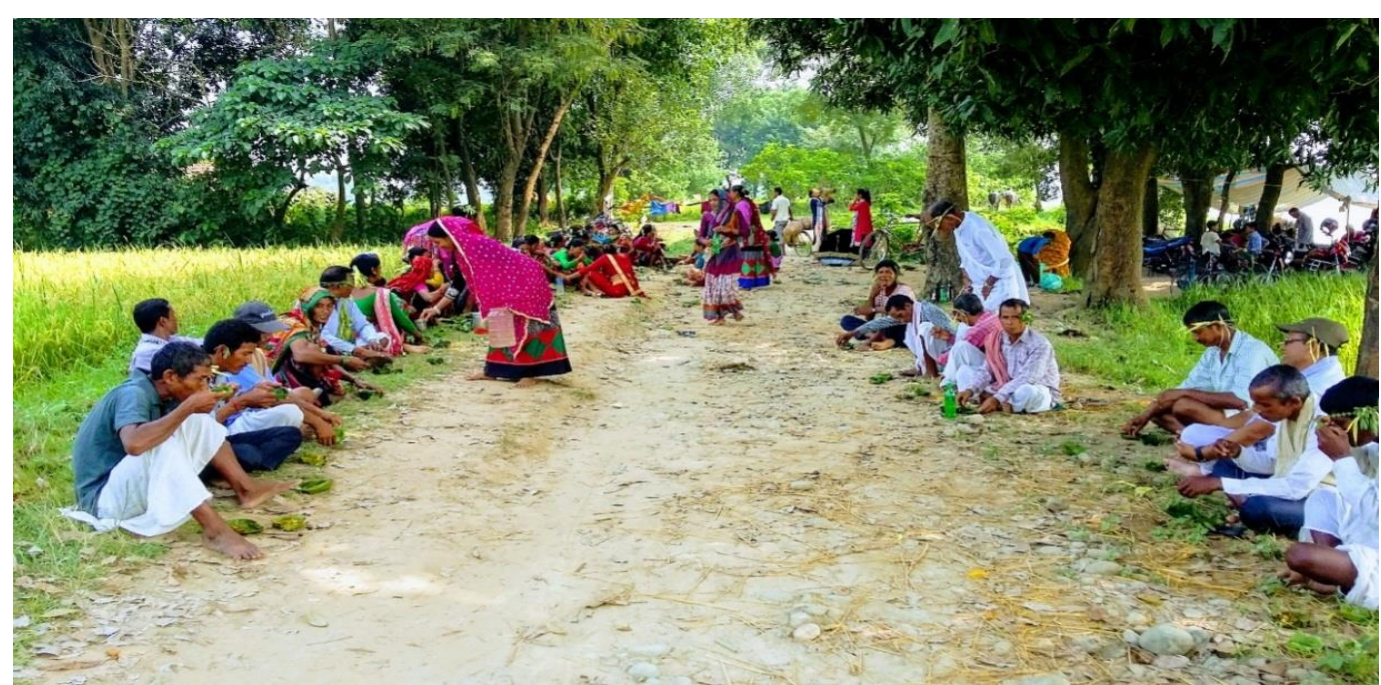

Fig. 3. A woman serving wine to the folks during Pittarhauwa at Khonpur village,

Kailari Village Council. 2017.

Source: Snapshot from the researcher's field visit

Additionally, in his another song Baba Mora Jotal ("My father ploughs the field"), Chaudhary resonates a kamaiya who is obliged to be the kamaiya due to his family lineage. The speaker gets upset with his children's miserable lives as they too lack a social agency. He blames the submissiveness of being a kamaiya for his wretched situation. He wishes to have education for better life. He aspires to discontinue his ancestral occupation:

Baba more jotal terwah haraho

Chhawa juni bhar jotabu

Aiho suno dai, baba, suno dadu bhaiya, suno mor didi bahiniya

Aiho chhai, chhawa ektho lari, ek huita duita pariya

Har jotaibo kahasam baba, abta mihin fe padhao

Aiho chhotimuti rana ho, gayaruwa banailo, gaunke school nai pathailo

Ho nengna, ghumna huinu chhegri charhainu,

Bara huinu banalu kamaiya

Aiho babu mora larka kheluiya, dai bati kamlahariya ("Baba Mor Jotal" 0:30-

My father ploughed with the bent plough

His son too will plough for his whole life

Oh listen brothers, sisters, listen sons and daughters, do not discriminate between sons and daughters

How long will you make me a plough boy!

Now please send me to school

You made me work as a shepherd when I was still a small boy,

Didn't send me to school

When I had just learned to walk on my own, I started looking after the cattles 
When I turned into adult, was forced to be a kamaiya,

Oh my sister is a babysitter; oh my mother is a kamlahari (Trans. is mine) The speaker condemns his parents' ignorance for ending up being a kamaiya throughout his entire life. The speaker's importune to his father to permit him to go to school so that he could understand the significance of education. The socially stifled life observed by the speaker arises as the aftereffect of his ignorance. Therefore, he considers education as the only way to end such practices.

Desh Raj Satgaunwa in his song Dukhiya Kamaiya ("The Sorrowful Kamaiya") explains the treacherous incident in a kamaiya's life due to conservative practice. The kamaiya considers Guruwa Kesauka ("Tharu priest") responsible for making his life more miserable. The local shamans just pretend to pray for his good life. They vow to resolve other's suffering on behalf of hen or lamb. But, on the contrary, these claims turn to be superstitions. They (shamans) request wine and rooster for conciliating the malicious spirits and conducting essential ceremonies to evade his miseries. In a hope of getting rid of such nuisance, the ignorant kamaiya believes them. He trusts that the guruwa would easily cast the evil out:

Mai dukhiya batu janamse Kamaiya, kon bidhi karbu gujara ho

Dai baba bata umerle burhaila, jingi bitaila kamaiya me ho

More upar bata soukik pahar, kaisik souki chhutaibu ho

Guruwa, kesauka milijuli jaitha jingi bhar kara jal sajhi ho ("Dukhiya Kamaiya" 0:30-3:00)

I a poor kamaiya from my birth

How will I be able to survive!

My father and mother have grown old, too lived their lives as kamaiya

I am burdened with the mounds of loans,

How will I be able to get rid of them!

The witchdoctor and the priest compromisingly conspire to benefit themselves

(Trans. is mine)

The speaker communicates the plotting of the guruwa who promises to improve his life. He discovers the performances of guruwa rather misleading. Their pseudo-practice turned out to be the primary reason for the dilapidated situation of the folks.

In recent times, the community has resigned from the conventional practice of their rituals. With the urbanization, those landless Tharus invested themselves more towards the income-generating exercises. Thus, to raise the collective awareness, many songs still promote literacy and empowerment efforts. Chaudhary in his folk song Matike Orauhna, Matike Bichhauna ("Dirt's bedsheet and dirt's cover") exemplifies the situation of a kamaiya. For him, the earth is the quilt and the bedsheet. He spends his whole life working on the farm. Chaudhary's folk song shows a kamaiya subjectivity from the hierarchy of caste and class. The kamaiya communicates his distress of having miserable life. He is unable to discharge the burden of Kamaiyahood. He relates his identity with the dry leaves of turmeric that wither gradually into pieces. Thus, a kamaiya too loses all his might to empower his agency:

Matike orauhna, matike bichhauna

Matike dehal e jaram ho

Kahe dehalo, isharu mahadev

Kamaiyan ke futal karam ho

Kaisin janam dehalo bhaganuwa

Juni bhar kamaiya ho,

Oiesika bitath, hamro jaramwa, jaise sukhi re hardik patiya ho

Chuliya parat jawai, kharhik dhana 
The Memory of Performance: From Contents to Contexts 25

Jaise barhai malikana ho

Hamra kamaiyan, nikhrat gaili

Jaise nikhari ghanak dhana ho

Fatat gail angiya kahi chunari ("Matike Orauhna, Matike Bichhauna" 0:30-3:00)

The earth's cover, the earth's sheet

The life born from this earth

Oh lord Shiva why you gave such wretched life to a kamaiya!

What kind of life you gave to suffer as the kamaiya!

Our life withers like the leaf of the green turmeric withers

At the end of the day, the landlords get a store of rice but we kamaiyas suffer penniles

We, kamaiyas kept on being marginalized like the farmer sweeps and throws away the scattered rice grains

Our clothes, shirt, blouse are worn out

We don't own anything (Trans. is mine)

The artist exemplifies the Tharu subjectivity, comparing it with the scattered grains of rice during threshing. He contrasts the Tharu culture with the recently sprouted buds of the mango tree and the privileged community with the honey bees. The relationship of those proficient community with the bees and the Tharus with flowers resemble the privileged and mistreated. He then compares a creation of the Tharu self with the pottery. The potter produces a distinct designed earthenware as per his wish. In a similar way, the Tharu's subjectivity is more of social fabrication than the biological growth. The narratives about the Tharus were constructed as per the will of the privileged class. Thus, such narratives cannot justify the retrospective Tharu subjectivity.

In a folk song Utho Kamaiya Tutal Jhopari ("Raise your voice kamaiya"), the artists like Somlal Chaudhary and Sitarami Chaudhary plea to resist the socio-political enslavement. The folk song resists the outcast of kamaiyas. Furthermore, they appeal the resilience against oppression. Since the exploitation cannot be tolerated, the immediate resistance becomes indispensable:

Utho Kamaiya aaj tuhare himmat karke

Soshan, daman, atyachar he jarsena ante karaike

Samaj banaina jimma Kamaiya, tuhar hatham ba ("Utho Kamaiya Tutal Jhopari" 0:30-3:00)

Rise! Rise! You kamaiyas, gathering your courage today

To end the violence, exploitation and oppression from the root (Trans. is mine)

This folk song reflects the strong resilience against oppression to infuse the agency in them. This performance was popular during the Maoist insurgency. It was a popular platform for the collective mobilization: political conference and local governance. It provided an opportunity for the Tharus to share their agency. They realized that their ignorance had been a reason for the inability to empower their agency.

\section{Conclusion}

In sum, this study finds the varying themes of agrestic behavior, daily chores, and living emotions: exaltation and despair inherent in the melodies of Dangaura Tharu folk dance. Since the dances are performed with the melodies to make them meaningful and contextual, the study on the melodies provides an immense insight into the Tharu community's prime way of life. In this way, the Tharu folk performance blends the narration of their memory and rituals. The performance helps the observers to learn about their lifestyle. It takes them to a tour of their memory. The narration of such performances holds the implicit philosophies of their tradition, memorizing the Kamaiya 
Practice, which had been their subjectivity once. The folk dances of the Tharu community hold the narratives of marginalization, peasantry and daily choirs. In recent times, the performance has become more commercialized with the interference of technology and professional approach. It has become part of their identity. They perform throughout the year to establish an agency. Most of them have become part of tourism through homestays. The discussion of their folklores has emerged as the field of study for further researchers. However, the performance should not merely be interpreted as aesthetic pleasure rather it should be inquired to apprehend their semantics. As Mark Johnson asserts, "We need a philosophy that sees aesthetics as not just art, beauty, and taste but reasonably as about how human beings experience and make meaning" (169). The acting body should not be observed only as the epitome of art and performance, but it should be analyzed as a prospective nucleus of new meanings and symbols.

\section{Works Cited}

"Baba ki Sagar Gainu." YouTube, uploaded by Budha Subba Digital, 8 Dec 2015, https://www.youtube.com/watch? $\mathrm{v}=8$ 0F8XkKsT8\&ab_channel=BudhaSubbaDigital

"Babake Sagaram Muriya Lahana Gainu." YouTube, uploaded by CS Films, 21 Dec 2020, https://www.youtube.com/watch?v=T7VE5qL bM\&ab_channel=CSFilms

"Barka Banwa Basanta." YouTube, uploaded by Siddhu Shayar, 2018, https://www.youtube.com/watch?v=AveRLxhZ-IM\&list=RDAveRLxhZ$\underline{I M \& s t a r t \text { radio=1\&ab channel=SiddhuShayar }}$

"Maina Buhran Tharu Movie Song." YouTube, uploaded by Budha Subba Digital, 22 Dec 2015, https://www.youtube.com/watch?v=cjJGFxEc7ss\&ab_channel=BudhaSubbaDig $\underline{\text { ital }}$

"Matike Orauhana Matike Bichhauna." YouTube, uploaded by HRK Music, Sept 232019 , https://www.youtube.com/watch?v=MGJ1QXsUkFk\&ab_channel=HRKMUSIC

"New Tharu Song Dukhiya Kamaiya." YouTube, uploaded by Kailali Music, 23 May 2020 , https://www.youtube.com/watch?v=2wat4IwEQn8\&ab_channel=KailaliMusic

“Old Tharu Lok Song Baba Mor Jotal.” YouTube, uploaded by Hamar Tharu Music, 21 July 2020,

https://www.youtube.com/watch?v=M9OlgW6iZwQ\&ab channel=HamarTharu $\underline{\text { Music }}$

"Old Tharu Song Har Jowata Uthal Kamaiya." YouTube, uploaded by Hamar Tharu Music, 16 Sep. 2020, https://www.youtube.com/watch?v=R9h8hoKX7CM\&ab_channel=HamarTharu Music

"Superhit Tharu Culture Song Jhumra." YouTube, uploaded by Rkc Digital, 5 Oct 2019, https://www.youtube.com/watch? $\mathrm{v}=$ wdjNdTISFug\&ab_channel=RkcDigital

“Tharu Cultural Video Baithakku.” YouTube, uploaded by Rkc Digital, 16 Sep 2019, https://www.youtube.com/watch? v=3fOue_jdN8\&ab_channel=RkcDigital

“Tharu Maina Folk Video Song." YouTube, uploaded by LUCKY digital, 4 May, 2020, https://www.youtube.com/watch?v=cPkMav5A01A\&ab channel=LUCKYdigital

"Utho Kamaiya Tharu Song." YouTube, uploaded by Ajrail Fulariya. RC, 6 July 2018, https://www.youtube.com/watch?v=Mm8D6GBbivQ\&ab channel=AjrailFulariy a.RC

Anderson, Graham. Greek and Roman Folklore: A Handbook. Greenwood Press, 2006. 
Barry, Phillips. "Some Aspects of Folk-Song." The Journal of American Folklore, vol. 25, no. 97, 1912, pp. 274-283. JSTOR, www.jstor.org/stable/534824. Accessed 6 July 2021.

Bascom, William R. "Four Functions of Folklore." The Journal of American Folklore, vol. 67, no. 266, 1954, pp. 333-349. JSTOR, www.jstor.org/stable/536411. Accessed 1 Mar. 2021.

Bauman, Richard. "Differential Identity and the Social Base of Folklore." The Journal of American Folklore, vol. 84, no. 331, 1971, pp. 31-41. JSTOR,www.jstor.org/stable/539731. Accessed 1 Mar. 2021.

Buckland, Theresa. "Definitions of Folk Dance: Some Explorations." Folk Music Journal, vol. 4, no. 4, 1983, pp. 315-332. JSTOR, www.jstor.org/stable/4522127. Accessed 6 July 2021.

Bunkse, Edmunds V. "Commoner Attitudes toward Landscape and Nature." Annals of the Association of American Geographers, vol. 68, no. 4, 1978, pp. 551-566. JSTOR,www.jstor.org/stable/2562143. Accessed 1 Mar. 2021.

Crum, Tom. "Is it Folklore or History? The Answer May Be Important." Folklore: In All of Us, In All We Do, edited by Untiedt, Kenneth L. U of North Texas P, 2006, pp. 3-12.

Dalzell, V. M. Freedom, Margins, and Music: Musical Discourses of Tharu Ethnicity in Nepal. 2015. UC Riverside, ProQuest ID: Dalzell_ucr_0032D_12351. Merritt ID: ark:/13030/m5xd3xvd, Accessed from https://escholarship.org/uc/item/0vg8n6pg

Deflem, Mathieu. "Ritual, Anti-Structure, and Religion: A Discussion of Victor Turner's Processual Symbolic Analysis.” Journal for the Scientific Study of Religion, vol. 30, no. 1, 1991, pp. 1-25. JSTOR, www.jstor.org/stable/1387146. Accessed 5 July 2021.

Dundes, Alan. "Folklore as a Mirror of Culture." The Meaning of Folklore: The Analytical Essays of Alan Dundes, edited by Simon J. Bronner, Utah State UP, 2007. pp. 53-66.

---. "Metafolklore and Oral Literary Criticism." The Meaning of Folklore: The Analytical Essays of Alan Dundes, edited by Simon J. Bronner, Utah State UP, 2007. pp. 77-87.

---. "The Study of Folklore in Literature and Culture: Identification and Interpretation." The Meaning of Folklore: The Analytical Essays of Alan Dundes, edited by Simon J. Bronner, Utah State UP, 2007. pp. 67-76.

Greenway, John. "Folk Songs as Socio-Historical Documents." Western Folklore, vol. 19, no. 1, 1960, pp. 1-9. JSTOR, www.jstor.org/stable/1497999. Accessed 6 July 2021.

Guneratne, Arjun. "Shaping the Tourist's Gaze: Representing Ethnic Difference in a Nepali Village." The Journal of the Royal Anthropological Institute, vol. 7, no. 3, 2001, pp. 527-543. JSTOR,www.jstor.org/stable/3134417. Accessed 1 Mar. 2021.

Johnson, Mark. The Meaning of the Body: Aesthetics of Human Understanding. The University of Chicago Press, 2007. https://www.pdfdrive.com/the-meaning-ofthe-body-aesthetics-of-human-understanding-d166580590.html. Accessed 6 July 2021.

Kapchan, Deborah A. "Performance." The Journal of American Folklore, vol. 108, no. 430, 1995, pp. 479-508. JSTOR, www.jstor.org/stable/541657. Accessed 6 July 2021.

McConachie, Bruce. "An Evolutionary Perspective on Play, Performance, and Ritual.” TDR (1988-), vol. 55, no. 4, 2011, pp. 33-50. JSTOR, www.jstor.org/stable/41407105. Accessed 6 July 2021.

Nancy Lee Chalfa Ruyter. "Some Musings on Folk Dance." Dance Chronicle, vol. 18, no. 2, 1995, pp. 269-279. JSTOR, www.jstor.org/stable/1567880. Accessed 6 July 2021. 
Rosen, Carol. "Performance as Transformation: Richard Schechner's Theory of the Play/Social Process Knot.” Salmagundi, no. 44/45, 1979, pp. 253-261. JSTOR, www.jstor.org/stable/40535933. Accessed 6 July 2021.

Schechner, Richard. Performance Studies: An Introduction. Taylor \& Francis e-Library, 2004.

Tharu, Ashok. "Tharu Folk Dance: Sakhya and Painya". Dances of Nepal. Edited by Govind Acharya. Nepal Music Center Trust, pp. 3-8.

Tongue, R. L. "Folk-Song and Folklore." Folklore, vol. 78, no. 4, 1967, pp. 293-303. JSTOR, www.jstor.org/stable/1259079. Accessed 6 July 2021.

Yengoyan, Aram A. "Clifford Geertz, Cultural Portraits, and Southeast Asia." The Journal of Asian Studies, vol. 68, no. 4, 2009, pp. 1215-1230. JSTOR,

www.jstor.org/stable/20619867. Accessed 5 July 2021.

\section{To cite this article [MLA style]:}

Dangaura, Mohan. "The Memory of Performance: From Contents to Contexts of Selected Tharu Folk Dances." SCHOLARS: Journal of Arts \& Humanities, vol. 4, no. 1, February 2022, pp. 11-28. NepJOL, doi:10.3126/sjah.v4i1.43050. 